\section{Costs of Capturing and Recycling Irrigation Water in Container Nurseries}

\author{
Nathaniel Ferraro, Darrell Bosch $\mathbf{1}$, and James Pease \\ Department of Agricultural and Applied Economics, Virginia Tech, \\ Hutcheson Hall, 250 Drillfield Drive, Blacksburg, VA 24060
}

James S. Owen, Jr.

Department of Horticulture, Virginia Tech, Hampton Roads Agricultural Research and Extension Center, Virginia Beach, VA 23455

Additional index words. partial budgeting, nursery economics, irrigation recycling

\begin{abstract}
In the future, the U.S. ornamental horticulture industry may be faced with limited water resources and increased requirements to reduce pollution runoff from production areas. The concerns are most evident to outdoor, uncovered container crop production, which relies on daily irrigation. Capture of precipitation and irrigation runoff from ornamental horticulture nurseries to be recycled as irrigation could potentially generate cost savings relative to the cost of alternative water sources. Existing nurseries may incur large investment costs to modify their infrastructure for water capture to recycle. These added costs must be compared with costs of alternative sources such as off-farm municipal or on-farm well water. Using both existing case nurseries and simulated nurseries, this study employed partial budgeting for comparison of annual costs of recapture and recycling to the alternatives of either municipally delivered water or on-farm well extraction. On-site visits were conducted at mid-Atlantic ornamental horticulture operations that recycle water currently to gather data for constructing budgets and to determine factors that enhance or inhibit nursery adoption of recycling. The partial budgeting analysis was followed by breakeven analysis with regard to costs of regrading, pond excavation, and opportunity costs of land to isolate their effects on the nursery adoption decision. Six of eight case nurseries currently obtaining from $20 \%$ to $100 \%$ of their irrigation needs from recycled water achieve lower production costs as a result of recycling compared with using alternative municipal or well water sources. Recycling would also reduce pollution runoff as water containing nutrients and chemicals would be retained for reuse on the farm rather than being discharged to public water bodies. Two case nurseries and two simulated nurseries that were constructed based on average conditions for nurseries participating in a mail survey see higher production costs as a result of recycling. The cost of land regrading for water recapture, excavating the recapture pond, and the opportunity cost of production area occupied by the recapture pond are critical for determination of the least cost outcome. Public funding incentives for water collection and recycling could motivate increased water conservation and reduced pollution runoff within the horticulture industry.
\end{abstract}

Household, commercial, and environmental demands for fresh water are increasing. As fresh water sources become scarcer, innovative technologies and policies must be developed to address and manage waterrelated business risks. Practices to capture and recycle water offer potential solutions to this problem by reducing consumption of water and extending its availability (Parsons et al., 2010). In the nursery crops industry, $\approx 5 \%$ of outdoor, uncovered operations nationwide recycle irrigation water (USDA, Economic Research Service, 2015; USDA, National Agricultural Statistics Service, $2014 a, 2014 b)$. This proportion is likely to increase as water scarcity becomes more acute in some regions and operations either discontinue agriculture or invest in building water capacity on-farm. Therefore, this project studies the impacts of the recycling investment on capital and operating costs of selected ornamental nurseries, as well as an
These costs may include such major investments as recontouring production areas to divert, capture, and store water; however, such structural changes may reduce scarce nursery production area. Moreover, adoption of recycled irrigation management practices may increase the risk of plant pathogen outbreaks, which increases the maintenance costs of the irrigation system.

The objectives of this study are 1) to estimate the cost of capture and recycling irrigation practices for case study and simulated ornamental nursery operations, 2) to compare such costs against an available alternative water source, and 3) to conduct a breakeven analysis to determine how changes in key factors may affect water sourcing choices. Partial, capital, and breakeven budget analyses were conducted to evaluate capital investments and operating expenses associated with a choice to capture and recycle water vs. sourcing it alternatively (Johnson, 1977; Rutgers Cooperative Extension, 2014; Wilkes, 1977). Three principal groups could benefit from this analysis: 1) nursery managers for whom comparative cost analyses of water supply choices provide information for helping choose among water supply sources or alternatives; 2) policy analysts, decision makers, and other stakeholders interested in comparative water recycling costs to assess benefits of recycling as a conservation practice to reduce freshwater consumption by the agricultural sector; and 3) allied suppliers that provide expertise in design and implementation of irrigation systems to assist clients in reducing both financial and environmental risk associated with growing nursery crops.

As businesses choose among alternative technologies or other investments they must address the question "Will investment A or investment B reduce expenses, generate more profit or both over the short and long term?" Choosing between alternatives is done most straightforwardly with a partial budget of annualized and discounted costs and returns. Partial budgets were used to consider marginal costs or returns specifically associated with the investment alternatives. If one alternative is a water recycling investment, additional costs could include such capital expenditures as construction of a water storage pond or noncash costs such as the forgone net income (opportunity costs) from previous production on the area now dedicated to the storage pond. The budget for a competing alternative may also include marginal returns and costs, such as metered water costs for municipal water. Any or all of the returns/ costs items could be annualized capital costs/ returns. The net returns of one alternative are then compared with net returns from the other. If the resulting choice is dependent on one or a few highly uncertain cost or return items, then key cost or return items can be varied one at a time to examine the sensitivity of the choice to each factor. This procedure is called breakeven budgeting, because the uncertain factor is increased or decreased such that the decision maker's resulting choice 
between alternatives would be indifferent (Castle et al., 1987). Users can then assess the likelihood that such an increase or decrease in cost needed to achieve breakeven will occur.

Partial budgeting of water management capital costs on farms was used to analyze investments required by irrigation with recycled water on a mixed crop farm in Queensland, Australia (Brennan et al., 2008). A similar study was conducted in New South Wales, Australia (Khan et al., 2008). Ørum et al. (2010) assessed incentives that Serbian farmers could receive by implementing new irrigation techniques to conserve water for tuber production.

Several costs in the partial budget are capital costs meaning they involve expenditures for items that provide services for more than 1 year. The decision framework known as capital budgeting offers several key indicators, such as payback period, net present value, and internal rate of return (Law,

Received for publication 22 Aug. 2016. Accepted
for publication 17 Nov. 2016 .
Funding for this work was provided by the Spe-
cialty Crop Research Initiative (SCRI) of
USDA-National Institute of Food and Agricul-
ture (NIFA) Award No. 2010-51181-21140, the
Virginia Agricultural Experiment Station and the
NIFA Hatch Program, U.S. Department of Agri-
culture.

Gordon Groover, Virginia Tech, and Anthony LeBude, North Carolina State University provided helpful review comments on an earlier version of the manuscript.

We would like to acknowledge the cooperation and information made available by the following individuals and organizations for technical and cost information assistance: Baltimore Public Works (2015) ("Past Water Rates," In J. Phillips-Farley ed. Baltimore Public Works, City of Baltimore); DC Water Authority (2004, DC Water Meter Sizing Worksheet, www.dcwater.com: District of Columbia Water and Sewer Authority); J. Donahoe (Personal Communication, Phone, 20 Jan. 2015); Farm Credit Systems of Virginia (Personal Communication, Phone, 17 Sept. 2014); E. Fischer (Personal Communication, Email, 30 Sept. 2014); B. Hamilton (Advanced Specialty Gases Company, Personal Contact, Web, 9 Sept. 2014); S. Hatcher (City Government of Isle of Wight, Engineering Department, Personal Communication, Phone, 16 Feb. 2015); D. Kennedy (Department of Development and Planning, Baltimore City Government, Personal Communication, Phone, 4 Feb. 2015); Lynchburg Crane Company (Personal Communication, Phone, 17 Sept. 2014); myAmortizationChart (2015) ("How is an Amortization Schedule Calculated," In myAmortizationChart.com, myAmortizationChart); Regal Systems International Incorporated (P.O. Box 1518, Stuart, FL 34995, Personal Communication, Email, 27 Aug. 2014); E. Spencer (ed.) (2008, RS Means Site Work \& Landscape Cost Data 2009, Rockland, Massachusetts: R. S. Means Company, Incorporated); Trading Economics (2014) (“United States Inflation Rate," In T. Economics ed. www.tradingeconomics.com, Trading Economics); WaterTanks.com (P.O. Box 340, Windsor, CA 95492, Web); Western Virginia Water Authority (601 S Jefferson St \#100, Roanoke, VA 24011, Personal Communication, Phone, 22 Sept. 2014).

${ }^{1}$ Corresponding author. E-mail: bosch@vt.edu.
2010), each functioning to compare alternative investments with useful lives longer than a single year. Capital costs can be annualized to spread the initial capital investment over its useful life so that annualized budgets of alternative investments can be compared. We compared annualized partial budget costs and returns consisting of both the investment expenditure made at initiation of the project and any associated operating expenses throughout the project life, and discounted to the present (time $=0$ ). Discounting accounts for inflation and the time value of money. We consider cash as well as noncash costs and returns. The latter consist primarily of opportunity costs incurred when returns are forgone by choosing one alternative for another.

Case studies described here present partial budgets developed to analyze costs and returns of alternative irrigation water sources on ornamental nurseries of varying sizes and in different locations. Partial budgets were developed to assess returns/ costs for recycling vs. alternative water sources (well or municipal water) on eight case nurseries in Pennsylvania (PA-1 and PA-2), Maryland (MD-1, MD-2, and MD3 ), and Virginia (VA-1, VA-2, and VA-3), each of which currently recycle at least some portion of rainfall and irrigation water. The cost/return assessment of these recycling nurseries is intended to represent the net cost of investments necessary to have developed the existing system of irrigation water capture and recycling in the year of nursery inception. That is, each nursery is placed in a pre-irrigation situation of choosing between recycling and a conventional alternative (well or municipal water).

\section{Materials and Methods}

The case study budgets were developed through on-site visits to investigate capital and annual costs associated with capturing and recycling water. On-site visits offered an opportunity to query managers regarding costs associated with land regrading, recapture ponds, and procedures for mitigating plant pathogens that increase risk when using recycled water. Both the nursery's own cost estimates and industry consultations were used to develop partial budgets for each nursery. Since the marginal tax brackets of nurseries and their owners were not determined, alternative investments were evaluated on a pre-tax basis. As noted, only marginal costs of each alternative to capturing and recycling are considered in the decision framework. Other factors not directly related to the technology choice are assumed to remain constant throughout the project period (Olson, 2003). For example, either recycling or its alternative (on-site groundwater extraction or off-site municipal water supply) would incur costs to pump water from ponds through the irrigation system to production areas. This cost is disregarded because it would be the same for recycling or an alternative to recycling. All costs and returns are annualized and are based on 2014 prices. Table 1 indicates the general characteristics of case study nurseries.

The data collected for this study include physical characteristics, such as area irrigated, type of irrigation system, and method of capturing and recycling water. Owners and managers were queried about their nursery's investment to capture and recycle irrigation water. All eight nurseries captured rainfall and irrigation water runoff in collection basins and recycled the water to supplement some portion of plant water needs.

We investigated physical modifications of the nursery, machinery and equipment purchased to allow recycling (including addition of pathogen mitigation equipment and materials), materials, and any change in labor practices to implement recycling on their production area supplied by recycling (Table 1). Current water usage for the summer or most active growing season was estimated. Winter usage per day for five fall and winter months when plants are dormant was assumed to be $10 \%$ of daily usage for the other 7 months. A small buffer pond to ensure water supply for a short period is assumed to store municipal water piped in or well water extracted onsite if one of those investment alternatives is chosen.

Partial budgets were constructed for all case study nurseries based on the reported amount of irrigation water needed with and without recycling. Although the Cultice survey (Cultice et al., 2016) identified several nurseries relying exclusively on captured and recycled rainfall for irrigation, these eight case nurseries in the present study employ

Table 1. Characteristics of eight case nurseries and two simulated nurseries used to compare costs for recycling and best alternative water source.

\begin{tabular}{llcccr}
\hline & \multicolumn{1}{c}{ State } & $\begin{array}{c}\text { Nursery } \\
\text { area (ac.) }\end{array}$ & $\begin{array}{c}\text { Nursery area in } \\
\text { production (ac.) }\end{array}$ & $\begin{array}{c}\text { Area in } \\
\text { containers (ac.) }\end{array}$ & $\begin{array}{c}\text { Area supplied by } \\
\text { recycling (ac.) }\end{array}$ \\
\hline VA-1 & Virginia & 2.5 & 2.5 & 1.3 & 0.4 \\
VA-2 & Virginia & 100 & 100 & 100.0 & 100.0 \\
VA-3 & Virginia & 400 & 200 & 200.0 & 200.0 \\
MD-1 & Maryland & 22 & 16.5 & 12.4 & 6.2 \\
MD-2 & Maryland & 105 & 105 & 2.1 & 2.1 \\
MD-3 & Maryland & 55 & 55 & 55.0 & 55.0 \\
PA-1 & Pennsylvania & 22 & 22 & 5.1 & 1.02 \\
PA-2 & Pennsylvania & 27 & 27 & 3.0 & 2.98 \\
SynSmall & Maryland & 13.6 & 13.6 & 13.6 & 0 \\
SynLarge $^{z}$ & Maryland & 88.9 & 88.9 & 88.9 & 0
\end{tabular}

${ }^{\mathrm{z}}$ Simulated nurseries assumed to be using $100 \%$ well water. 
recycling to varying degrees. VA-2, VA-3, and MD-2 use recycled rainfall and irrigation runoff for all their water needs (Table 1). The default (control) partial budget represents complete use of recapture and recycling, while the alternative represents complete use of municipal or well water on the same area. MD-3 and PA-2 also rely exclusively on recycling in normal years, but if shortages occur, both have the ability to access well water or municipal water. In this case, the initial budgets for MD-3 and PA-2 reflect $100 \%$ recycling, while the alternative is $100 \%$ well water for MD-3 and $100 \%$ municipal water for PA-2.

The three remaining nurseries (VA-1, MD-1, and PA-1) are partial adopters of recycling. The partial budgets reflect only costs that vary depending on whether water is recycled or obtained from an alternate source. For example, the VA-1 initial budget represents $66 \%$ well water and $34 \%$ recycled water, while the alternative budget represents $66 \%$ well water and $34 \%$ municipal water, due to lack of additional well capacity on the property. Thus the partial budget reflects costs for $34 \%$ of the water supply that is obtained from either recycled or municipal water. The well water costs are not considered as these costs do not change if municipal water is substituted for recycling. The MD-1 budget represents current use of $50 \%$ well water and $50 \%$ recycled, while the alternative is $100 \%$ well water. The final case nursery (PA-1) supplements use of well water with recaptured and recycled water. The initial budget reflects $80 \%$ well water and $20 \%$ recycled water, while the alternative is $100 \%$ well water.

In addition, two simulated nurseries representing characteristics and practices in survey responses were constructed (Cultice et al., 2016). The simulated nurseries were constructed to analyze the recycling decision from the perspective of a typical nursery using well water as its principal water source. Characteristics of the nurseries were based on those of $\mathrm{MD}, \mathrm{PA}$, and VA nurseries who are not currently recycling and who responded to a mail survey dealing with irrigation and recycling (Cultice, 2013). Principal simulated nursery characteristics were distinguished as small nurseries (SynSmall) if gross revenues were $\$ 500,000$ or less $(n=160)$, and large nurseries (SynLarge) if gross revenues were greater than $\$ 500,000(\mathrm{n}=35)$. Of the 195 nurseries indicating costs and revenues, water usage, and water extraction methods, $92 \%$ of irrigation water was supplied by wells. Most surveyed nurseries do not capture irrigation water and rainfall from any portion of their production area (Cultice, 2013), therefore no capture of rainfall or irrigation runoff for recycling was assumed for the simulated nurseries. In contrast to the analysis of case study nurseries, the default (control) technology is well water extraction with no recycling, and the alternative technology is recycling with pathogen mitigation. Because of Maryland's additional regulatory requirements for groundwater extraction, both nurseries are assumed to be located in the Maryland Piedmont region and to have deep wells to extract water. Maryland has the most restrictive and expensive regulations for well drilling, which presents the most favorable case for recycling technology (Maryland Department of the Environment, 2014; Spencer and Babbitt, 2008).

Based on survey responses, the small simulated nursery generates gross revenue of $\$ 104,297$ on a production area of 13.6 acres, while the large simulated nursery earns $\$ 2,027,778$ gross revenue on container production from 88.9 acres. Both simulated nurseries are assumed to use groundwater from a nonlimiting well using a 5 horsepower electric centrifugal drive pump.

Similar to the analysis of case study nurseries, all costs were assumed to be incurred at the time of nursery establishment and pertain only to expenses and revenues incurred based on the decision about water source made at that time. Capital and operating costs for pathogen control were included for nurseries with recycling systems. Capital costs were amortized on an annual basis. The annualized finance cost of capital investments depends on the useful life of the investment (which may vary depending on the capital item) and the real (inflation free) interest rate (Johnson, 1977; Wilkes, 1977). The real interest rate is the firm's deflated weighted average cost of capital, based on borrowed funds and the opportunity cost of equity capital (Boehlje and Eidman, 1984). A 30 -year project period was used as the functional life of the recycling pond and associated drainage ditches. Some elements such as pumps would be purchased multiple times over the project period. It is assumed that salvage values for capital items are zero at the end of their useful lives.

\section{Results}

An example of the partial budgets is illustrated in Table 2 for Nursery VA-2.
Nursery VA-2 is located in the Virginia coastal plain, was established $\approx 45$ years ago as a wholesale producer, and has recently moved into retail sales.

This 100 -acre nursery has a large collection pond that is supplied by rainfall or irrigation runoff captured by drainage ditches delivering water through multiple collection/ recapture ponds. Irrigation water is treated by a chlorine gas system before application by overhead or drip nozzles to irrigated container ornamental crops.

This analysis reconstructed the partial budget costs and returns before installation of the current recycling system (in \$2014). The control technology is captured and recycled water, while the best alternative is municipal water piped onto the site. The control costs include regrading of the production area and dredging of a recapture pond, a chlorine gas and injection system, copper additives to suppress algae in the pond, and the opportunity cost of the land area used for the pond. This opportunity cost is estimated as the revenue per square foot of production area multiplied by forgone returns if recycling were chosen and the land converted to a recycling pond. Alternative costs include the cost of digging a small buffer pond to store municipal water and ensure even flows during peak pumping, a yearly charge for city water, a water connection fee, a water availability charge, a meter service charge, and a water treatment charge. The cost difference between the two alternatives can be seen as cost savings that a nursery could capture by choosing the least cost option. Table 2 shows that for Nursery VA2 , the cost of municipal water is some five times greater than that of captured and recycled water.

Control and alternative partial budgets are presented in summary form below, which shows the capture and recycling and munic$\mathrm{ipal} /$ well water alternative costs for each case

Table 2. Estimated annual recycling and municipal water supply costs for Virginia case Nursery VA-2.

\begin{tabular}{lrlr}
\hline \multicolumn{2}{c}{ Alternative 1: 100\% capture/recycling } & \multicolumn{2}{c}{ Alternative 2: 100\% municipal water ${ }^{\mathrm{y}}$} \\
\hline Regrading fields & $\$ 155,885$ & Municipal water hook up & 153 \\
Selling regraded soil & $(\$ 93,531)$ & Price of municipal water & $1,311,497$ \\
Dredging & 20,019 & Treatment of pH in municipal water & 2,141 \\
Chlorine & 28,000 & Water availability charge & 38,488 \\
Chlorine system & 171 & Meter service charge & 731 \\
Copper & 661 & Digging of buffer pond & 36,984 \\
Digging recapture pond & 59,150 & Opportunity cost of buffer pond & 15,382
\end{tabular}
Opportunity cost of recapture pond ${ }^{\mathrm{z}} \quad 24,597$ Total for recapture/recycling $\$ 194,952$ Recapture/recycling cost savings $\$ 1,210,425$

Total for municipal water

$\$ 1,405,377$

${ }^{\mathrm{z}}$ Assumptions: Investment costs were amortized at a $4.7 \%$ real interest rate. Regrading cost assumes 100 acres regraded at a cost of $\$ 2,475,000$ amortized over 30 years. Sale of regraded soil covers $60 \%$ of excavation costs. Dredging cost is $\$ 1.25$ /square foot over entire area of pond (4.3 acres) amortized over 15 years. Chlorine cost based on 3,750 lbs per year at $\$ 7.46 / \mathrm{lb}$. Chlorine system costs equal $\$ 2,000$ amortized over 15 years. Copper applied at 2 gallons per application for six applications per summer. Digging cost is based on 187,041 square feet (4.3 acres) excavated at a cost of $\$ 944,000$ amortized over 30 years (Homewyse, 2015). Opportunity cost based on estimated gross revenue minus operating costs $=\$ 5,660$ / acre for 4.3 acres.

${ }^{y}$ Municipal hookup cost based on initial cost of $\$ 2,500$ for a 10 -inch water meter amortized over 30 years. Municipal water price equals wholesale water rate of $\$ 0.0058289$ per gallon ( $\$ 4.36$ per 100 cubic feet) for $225,000,000$ gallons/year. Treatment of $\mathrm{pH}$ cost based on a 3,500 gpm filter with an initial cost of $\$ 25,000$ amortized over 15 years. Water availability charge is $\$ 620,000$ amortized over 30 years. Digging cost is based on 116,970 square feet $(2.7$ acres) excavated at a cost of $\$ 590,000$ amortized over 30 years (Homewyse, 2015). Opportunity cost based on estimated gross revenue minus operating costs $=\$ 5,660$ / acre for 2.7 acres. 
Table 3. Estimated annual water supply cost comparison of recycling versus best alternative (municipal and/or well water) for eight case nurseries.

\begin{tabular}{|c|c|c|c|c|c|c|c|c|}
\hline & $\begin{array}{l}\text { VA-1 }(34 \% \\
\text { recycling, } \\
66 \% \text { well })\end{array}$ & $\begin{array}{l}\text { VA-2 (100\% } \\
\text { recycling) }\end{array}$ & $\begin{array}{c}\text { VA-3 (100\% } \\
\text { recycling) }\end{array}$ & $\begin{array}{l}\text { MD-1 }(50 \% \\
\text { recycling, } \\
50 \% \text { well })\end{array}$ & $\begin{array}{l}\text { MD-2 (100\% } \\
\text { recycling) }\end{array}$ & $\begin{array}{c}\text { MD-3 (100\% } \\
\text { recycling) }\end{array}$ & $\begin{array}{l}\text { PA-1 }(20 \% \\
\text { recycling, } \\
80 \% \text { well })\end{array}$ & $\begin{array}{c}\mathrm{PA}-2(100 \% \\
\text { recycling) }\end{array}$ \\
\hline $\begin{array}{l}\text { Cost of } \\
\quad \text { recapture/recycling }(\$)\end{array}$ & 4,452 & 194,952 & 475,420 & 4,339 & 160,174 & 176,338 & 54,565 & 46,354 \\
\hline Cost of alternative & 6,095 & $1,405,377$ & 988,468 & 9,770 & 281,331 & 9,043 & 55,259 & 22,331 \\
\hline Description of alternative & $\begin{array}{l}66 \% \text { well, } \\
34 \% \\
\text { municipal }\end{array}$ & $\begin{array}{l}100 \% \\
\text { municipal }\end{array}$ & $\begin{array}{l}100 \% \\
\text { municipal }\end{array}$ & $100 \%$ well & $\begin{array}{l}100 \% \\
\text { municipal }\end{array}$ & $100 \%$ well & $100 \%$ well & $\begin{array}{l}100 \% \\
\text { municipal }\end{array}$ \\
\hline $\begin{array}{l}\text { Cost advantage } \\
\quad \text { recapture/recycling }(\$)\end{array}$ & 1,643 & $1,210,425$ & 513,048 & 5,431 & 121,157 & $-167,295$ & 694 & $-24,023$ \\
\hline $\begin{array}{l}\text { Recapture/recycling } \\
\text { cost as } \% \text { of nursery } \\
\text { production costs }\end{array}$ & 12.7 & 2.8 & 6.6 & 0.3 & 7.6 & 7.2 & 2.5 & 33.1 \\
\hline
\end{tabular}

Table 4. Estimated annual well water supply costs on two constructed simulated nurseries.

\begin{tabular}{lccccc}
\hline & \multicolumn{2}{c}{ Simulated small } & & \multicolumn{2}{c}{ Simulated large } \\
\cline { 2 - 3 } \cline { 5 - 6 } Item & Cost $(\$)$ & Percentage of total & & Cost $(\$)$ & Percentage of total \\
\hline Well digging & 8,215 & 70 & 1 & 34,229 & 69 \\
State permits & 119 & 7 & & 425 & 1 \\
Well pump cost and installation & 831 & 710 & 7 & 3,464 & 7 \\
Buffer pond digging & 842 & 8 & 3,417 & 7 \\
Well pump electricity consumption & 993 & & & 3,508 & 7 \\
Opportunity cost of buffer ponds & 11,811 & & 49,807 & 10 \\
Totals & & & &
\end{tabular}

${ }^{\mathrm{z}}$ Columns may not sum to $100 \%$ due to rounding.

Table 5. Estimated annual recycling water supply costs on two constructed simulated nurseries.

\begin{tabular}{lrrrrr}
\hline & \multicolumn{2}{c}{ Simulated small } & & \multicolumn{2}{c}{ Simulated large } \\
\cline { 2 - 3 } \cline { 5 - 6 } Item & Cost $(\$)$ & \% of total & & Cost $(\$)$ & Percentage of total \\
\hline Regrading & 6,447 & 20 & & 103,960 & 32 \\
Chlorine system & 171 & 1 & & 171 & 0 \\
Smart valve & 642 & 2 & & 642 & 0 \\
Chlorine costs & 1,540 & 5 & & 6,497 & 2 \\
Dredging & 4,964 & 15 & & 41,093 & 13 \\
Recapture pond digging & 13,646 & 42 & & 122,209 & 38 \\
Opportunity cost of recapture pond & 5,368 & 16 & & 50,491 & 16 \\
Totals & 32,779 & & & 325,064 & \\
\hline
\end{tabular}

nursery (Table 3). The cost difference indicates cost savings that the nursery could obtain by choosing the lowest cost option. The recapture/recycling costs are also expressed as percentages of each nursery's total production costs, giving perspective to the size of the recycling cost relative to reported annual production costs.

Six of the eight case nurseries achieve lower costs by recycling. Total cost savings from recycling range from only $\$ 694$ to more than $\$ 1.2$ million per year. For perspective on the impact of such an investment, recycling cost as a percentage of annual production costs for the six nurseries ranges from $0.3 \%$ to $12.7 \%$. The largest cost items for implementing capture and recycling are regrading the production area and digging a recycling pond. The latter cost includes not only cash costs for digging the pond, but also the opportunity cost of forgoing the ability to grow saleable products on the land area sacrificed for the pond. Four nurseries required regrading (VA-1, VA-2, VA-3, and MD-2) that cost an average $46 \%$ of their total recycling budget. Seven of the eight nurseries would incur costs ranging from $16 \%$ to $72 \%$ of total recycling costs for pond excavation (the exception, VA-1, stores water in large tanks). In the cases of MD-2 and PA-2, more than two-thirds of water recycling costs would be incurred for pond excavation. These seven nurseries incur a noncash opportunity cost of $9 \%$ to $25 \%$ of their recycling budget by forgoing production on the area occupied by the recycling pond.

The two remaining case nurseries would incur much larger costs for recycling than for well or municipal water, and have no costsaving reason to adopt recycling. Nursery PA-2 could save costs by tapping into an easily accessible municipal water source. To recycle substantially more rainfall and irrigation runoff, Nursery MD-3 would have to invest in regrading the production area and digging a recapture pond, using scarce production area for the pond. Instead, groundwater in the area surrounding the nursery is abundant and the cost of extracting more water for irrigation would be relatively inexpensive.

The above results suggest that many nurseries in the Mid-Atlantic region could reduce costs by adoption of recycling. However, additional insight is provided by examining the choice for simulated nurseries. A large majority of surveyed nurseries do not capture or recycle and most have relatively easy access to sufficient well water, so it was assumed that the default (control) water source of the small and large simulated nurseries would be $100 \%$ well water (Rees et al., 2015). The alternative technology for the simulated nurseries is to capture and recycle precipitation and irrigation runoff. The principal expense for well water extraction is the cost of drilling, followed by the nonmonetary opportunity cost of a buffer pond, installation of well pumps, electricity for pumps, and costs of digging ponds (Table 4). The principal expenses for water recycling are pond excavation, regrading, pond dredging, and the opportunity cost of land used for the buffer pond (Table 5). The costs of chlorine and chlorination injection system for plant disease control are relatively small. The regrading costs are a function of the amount of soil excavated, which is directly related to the irrigated area of the operation and thus varies substantially between the small and large nurseries.

Tables 4 and 5 suggest that under these assumptions, both small and large nurseries with good access to groundwater would minimize production costs by extracting more well water rather than adopting recycling. The simulated nurseries would have lower irrigation costs using well water due to recycling's large capital expenses for regrading and digging a recapture pond. In addition, the opportunity cost of land sacrificed for a recycling storage pond is substantial. Key factors determining the technology choice are groundwater resource availability, the costs of regrading, and the net revenue forgone from production area used for the storage pond.

We evaluated the robustness of results for both the case study and simulated nurseries with breakeven analysis, which provides information about the riskiness of the chosen investment. The analysis uses the principal cost factors and determines the change that causes the two investments to become equal, through which the decision maker can assess how likely such an unexpected change might occur. The principal costs factors for the recycling decision are regrading cost and the combination of storage pond excavation cost and opportunity cost for the excavation. Looking first at the latter cost factors, Table 6 indicates for the five nurseries for which a storage pond was required and yet recycling 
is the best option, the percentage increase in pond excavation and opportunity costs necessary to make the investment choices equal. In four of the five cases, relatively large increases in such costs $(79 \%$ to $1,445 \%)$ would be needed to make recycling and nonrecycling of equal cost. In one case, PA1 , a small $2 \%$ increase of excavation and opportunity costs would make capture/ cost. Not surprisingly, the implication of these results is that there are likely to be many situations where recycling is cost effective even with large changes in pond excavation and opportunity costs from those used here.

Three case nurseries (all Virginia nurseries) would require regrading to adopt recycling. Table 7 indicates the sensitivity of regrading cost for the choice of recycling. Results indicate that for recycling cost savings to be eliminated, regrading costs would have to increase by $104 \%, 776 \%$, and $164 \%$ of budgeted costs. It is unlikely that misestimation of regrading costs alone would undermine the validity of the recycling decision.

For nurseries for which well water or municipal water has the lower cost (MD-3, PA-2, simulated small, and simulated large), what increase in annualized well or municipal water costs would make recycling and nonrecycling equal in cost? In Table 8 , the least cost water source (well water, municipal system) for these nurseries is indicated below the nursery name. The table indicates that MD-3 well water investment cost must increase by $1,850 \%$ for recycling costs to equal alternative sourcing costs. This nursery would incur very large costs for recontouring the property for irrigation water recycling and nonrecycling to be of equal

recapture (regrading is $51 \%$ of recycling investment), as well as incurring substantial investment cash costs for digging the recapture pond and noncash costs for land dedicated for that investment. For PA-2, well or municipal water access investment would have to increase by $108 \%$ to equal costs of recycling, a substantial but not inconceivable amount that could flip the least cost alternative to recycling. The small simulated nursery's costs are closer to breakeven. If recycling costs were lowered by $64 \%$, then recycling would be equal in cost to well or municipal water access. If such cost savings were realized in digging the recapture pond ( $42 \%$ of total recycling cost), recontouring $(20 \%)$, or the opportunity of forgone land area for the recapture pond $(16 \%)$, then recycling could become the preferred choice. Alternatively, if costs of well water increased by $178 \%$, well water and recycling would be equal in cost. On the large simulated nursery, well water investment costs would have to increase by $553 \%$ or recycling costs would have to decrease by $85 \%$ in order for well water to be at breakeven with recycling. Both changes are unlikely.

\section{Conclusions}

The business choice of capture/recycling rainfall and irrigation runoff vs. nonrecycling alternative water sources was examined with partial budgets based on characteristics of operating case nurseries and on representative characteristics of horticultural operations collected in a Mid-Atlantic survey. The recycling budgets incorporate investments and operations to capture and store water and to mitigate potential pathogen contami-

Table 6. Increased pond excavation and opportunity costs required to make recycling water supply costs equivalent to costs of best water supply alternative.

\begin{tabular}{lrccrr}
\hline & VA-2 (\$) & VA-3 (\$) & MD-1 (\$) & MD-2 (\$) & PA-1 (\$) \\
\hline Cost advantage/recycling & $1,210,424$ & 514,345 & 5,431 & 121,157 & 694 \\
Pond excavation + opportunity cost & 83,747 & 391,690 & 2,052 & 152,757 & 43,497 \\
Percent increase to make choice & 1,445 & 131 & 265 & 79 & 2 \\
$\quad$ indifferent (\%) & & & & &
\end{tabular}

Table 7. Increased regrading costs required to make recycling water supply costs equivalent to costs of best water supply alternative.

\begin{tabular}{lcrr}
\hline & VA-1 (\$) & VA-2 (\$) & VA-3 (\$) \\
\hline Cost advantage/recycling & 1,643 & $1,210,425$ & 514,345 \\
Regrading cost & 1,579 & 155,885 & 312,967 \\
Percent increase to make choice indifferent (\%) & 104 & 776 & 164 \\
\hline
\end{tabular}

Table 8. Increased well or municipal cost required to make well or municipal supply costs equivalent to recycling costs.

\begin{tabular}{lcccr}
\hline & $\begin{array}{c}\text { MD-3 } \\
\text { (well } \\
\text { water) }(\$)\end{array}$ & $\begin{array}{c}\text { PA-2 } \\
\text { (municipal } \\
\text { water) }(\$)\end{array}$ & $\begin{array}{c}\text { SynSmall } \\
\text { (well } \\
\text { water) }(\$)\end{array}$ & $\begin{array}{c}\text { SynLarge } \\
\text { (well } \\
\text { water) (\$) }\end{array}$ \\
\hline $\begin{array}{l}\text { Cost advantage/well or municipal } \\
\text { Well or municipal cost }\end{array}$ & 167,295 & 24,023 & 20,968 & 325,064 \\
$\begin{array}{l}\text { Percent decrease recycling cost to } \\
\text { make choice indifferent (\%) }\end{array}$ & 9,043 & 22,331 & 11,811 & 49,807 \\
$\begin{array}{l}\text { Percent increase well or municipal } \\
\text { cost to make choice indifferent (\%) }\end{array}$ & 95 & 52 & 64 & 85 \\
\hline
\end{tabular}

nation for $20 \%$ to $100 \%$ of the irrigated nursery area. Of the eight case nurseries, six nurseries achieved lower annualized costs for capturing and recycling water compared with an alternative "next best" water source of onfarm wells or off-farm municipal water. One nursery would have lower costs for the nonrecycling alternative of on-farm wells and another for accessing municipal water.

For the small and large simulated nurseries constructed from average characteristics of nurseries surveyed by Cultice et al. (2016), with sufficient on-farm groundwater access and nonrestrictive regulations, well water was the most cost-effective water source. Recycling in these "typical" example nurseries was not cost-effective because of regrading costs, recapture pond excavation costs, and opportunity costs of the production area sacrificed for excavation of the pond.

Not surprisingly, the choice of recycling often hinges on water resource availability and cost. If on-farm well water is available in sufficient volumes for nursery production, much of the incentive to recapture and recycle disappears. If the nursery is in a beneficial market location close to a metropolitan area, nursery land is likely to be more restricted and available only at a higher purchase price resulting in a high opportunity cost for forgone land if recycling is considered. Nurseries with available groundwater resources and limited or high-cost land availability will be unlikely to adopt capture and recycling because of economic disincentives. However, other factors may encourage recycling. Several nursery owners indicated that they chose to capture and recycle water because of concerns about future water shortages, concerns about future regulatory restrictions on water extraction or discharge requirements, and concerns about environmental choices.

State and/or federal subsidy programs could be implemented or expanded to subsidize nursery recycling investments such as terrain regrading and recapture pond excavation. Such shared public/private investments could incentivize rainfall and irrigation water runoff recapture and result in increased savings for growers, reduce depletion of groundwater, and reduce pollution runoff. Other research indicates that environmentally conscious purchasers of ornamental plants may be willing to pay premiums for plants grown with recycled water (Hartter, 2012). If growers could capture some of this benefit, premiums could compensate for recapture and recycling investments and affect decisions to adopt recapture and recycling.

\section{Literature Cited}

Boehlje, M.D. and V.R. Eidman. 1984. Farm management. Wiley, New York.

Brennan, L.E., S.N. Lisson, P.L. Poulton, P.S. Carberry, K.L. Bristow, and S. Khan. 2008. A farm-scale, bio-economic model for assessing investments in recycled water for irrigation. Austral. J. Agr. Res. 59:1035-1048.

Castle, E.N., M.H. Becker, and A.G. Nelson. 1987. Farm business management: The decisionmaking process. MacMillan, New York. 
Cultice, A., D. J. Bosch, J. Pease, K.J. Boyle, and W. Xu. 2016. Horticultural growers' willingness to adopt recycling of irrigation water. $\mathrm{J}$. Agr. Appl. Econ. 48(1):99-118.

Cultice, A.K. 2013. Horticultural producers' willingness to adopt water recycling technology in the Mid-Atlantic region. Master's thesis, Department of Agricultural and Applied Economics, Virginia Polytechnic Institute and State University, Blacksburg, VA.

Hartter, D. 2012. Understanding consumers' ornamental plant preferences for disease-free and water conservation labels. Master's Thesis, Department of Agricultural and Applied Economics, Virginia Polytechnic Institute and State University, Blacksburg, VA.

Homewyse. 2015. Cost to dig a pond. Pond Digging Cost Calculator. 1 June 2015. $<\mathrm{http} / /$ www.homewyse.com/services/cost_to_dig pond.html>.

Johnson, R.W. 1977. Capital Budgeting. Kendall/ Hunt, Dubuque, IA.

Khan, S., A. Abbas, H.F. Gabriel, T. Rana, and D. Robinson. 2008. Hydrologic and economic evaluation of water-saving options in irrigation systems. Irrig. Drain., 57:1-14, doi:10.1002/ ird.
Law, J. (ed.). 2010. Dictionary of Accounting, 4th ed. Oxford University Press, Oxford.

Maryland Department of the Environment. 2014. Water Management Permits: Water Management Administration. 7 Jan. 2016. <http:// www.mde.state.md.us/programs/Permits/ WaterManagementPermits/Pages/Permits/ WaterManagementPermits/>.

Olson, K. 2003. Farm Management: Principles and Strategies. Wiley-Blackswell, Hoboken, NJ.

Ørum, J.E., M.V. Boesen, Z. Jovanovic, and S.M. Pedersen. 2010. Farmers' incentives to save water with new irrigation systems and water taxation-A case study of Serbian potato production. Agr. Water Mgt., 98(3):465-471, doi: 10.1016/j.agwat.2010.10.019.

Parsons, L.R., B. Sheikh, R. Holden, and D.W York. 2010. Reclaimed water as an alternative water source for crop irrigation. HortScience 45:1626-1629.

Rees, G., A. Cultice, J. Pease, D. Bosch, and K. Boyle. 2015. Irrigation Systems and Practices in Mid-Atlantic Nurseries. American Nurseryman Magazine, Feb. 10, 2015. 7 Jan. 2016. <http://www.amerinursery.com/ water-management/irrigation-systems-andpractices-in-mid-atlantic-nurseries/>.
Rutgers Cooperative Extension. 2014. Partial Budgeting: A Financial Management Tool. New Brunswick, New Jersey, New Jersey Agricultural Experiment Station.

Spencer, E.R. and C. Babbitt. 2008. RS Means Site Work \& Landscape Cost Data 2009. R. S. Means Company, Rockland, MA.

U.S. Department of Agriculture (USDA), Economic Research Service. 2015. Irrigation and water use. 28 Dec. 2015. <http://www.ers. usda.gov/topics/farm-practices-management/ irrigation-water-use/background.aspx $>$.

U.S. Department of Agriculture (USDA), National Agricultural Statistics Service. 2014a. Farm and Ranch Irrigation Survey (2013). Volume 3, Special Studies, Part 1, AC-12-SS1. 28 Dec. 2015. <http://www.agcensus.usda.gov/ Publications/2012/Online_Resources/Farm_ and_Ranch_Irrigation_Survey/>.

U.S. Department of Agriculture (USDA), National Agricultural Statistics Service. 2014b. Census of Horticultural Specialties, 2012 Census of Agriculture, Volume 3 Special Studies Part 3 AC-12-SS-3.

Wilkes, F.M. 1977. Capital Budgeting Techniques. Wiley, London and New York. 